\title{
Fears of cults and kooks push Congress towards cloning ban
}

\section{Paul Smaglik, Washington}

The United States is moving closer to outlawing human reproductive cloning after a dramatic congressional hearing drew attention to the prospect that attempts to clone a human are imminent.

But despite agreement on Capitol Hill that such experiments should be banned, the means of achieving a ban remain elusive. Scientific societies fear that any proposed legislation might be amended by opponents of abortion to ban not only human cloning, but also therapeutic cloning and other scientifically useful work.

Billy Tauzin (Republican, Louisiana), chair of the House Committee on Energy and Commerce, whose investigations subcommittee held the hearing on 28 March, said before the hearing that he had not decided whether to propose legislation. But several committee members said during the hearing that legislation was necessary, and Tauzin's staff said later that he may introduce a bill when Congress reconvenes after Easter.

The hearing was triggered by claims from two research groups that each intends to clone a human soon. Both groups were asked to testify at the hearing, despite some scientists' concerns that this would alarm and confuse the public.

A company called Clonaid, founded by a man who claims extraterrestrials told him to change his name to Raël, and whose parent group, Valiant Venture Ltd, is registered in the Bahamas, says it plans to clone a human at an undisclosed location in the United States. Raël told the hearing that the human race had been cloned by extraterrestrials and that it was our duty to clone ourselves.

An international group of reproduction specialists, meanwhile, has announced plans to use human cloning as a technique to help infertile couples have children (see Nature

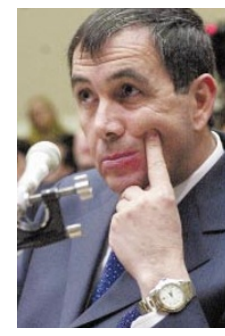
410, 293; 2001). Neither Brigitte Boisselier, Clonaid's scientific director, nor Panos Michael Zavos, a partner in the other effort, has ever successfully cloned an animal.

Other witnesses sought to draw distinctions between good and bad sciPanos Zavos: would pre-screen human embryos. ence and between safety and ethics. Congress's perception of such distinctions is likely to shape any legislation or regulation of cloning. A focus on safety, rather than ethics, might provide a basis for regulation by the Food and Drug Administration, the hearing was told.

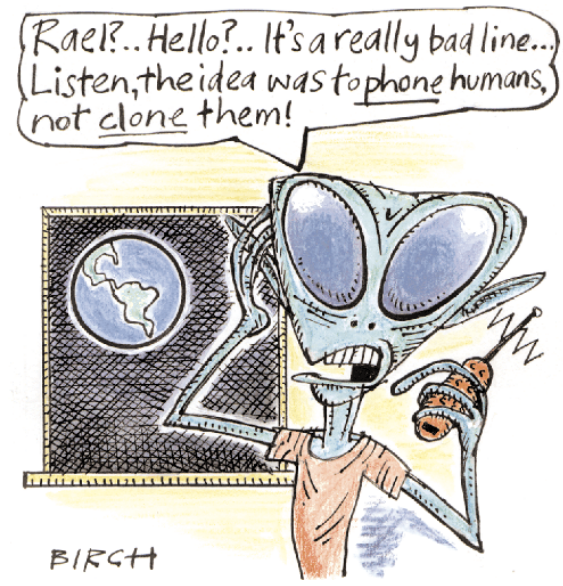

Arthur Caplan, head of the Center for Bioethics at the University of Pennsylvania, told the hearing that immediate safety concerns should supercede any ethical discussion. Such concerns are so great, he said, that only "cults, cranks, kooks and capitalists" would propose cloning a human given the known risks.

Thomas Okarma, president of the California-based biopharmaceutical company Geron, testified on behalf of the Biotechnology Industry Organization. He said human reproductive cloning should be banned for safety reasons, because the success rate in animals is between 3 and $5 \%$.

Boisselier claimed that success rates in animals were no indication of the technique's efficacy in humans. And Zavos said his group would pre-screen the viability of embryos before implanting them.

Rudolf Jaenisch, a professor of biology at the Massachusetts Institute of Technology, said these arguments contained "serious factual errors", the most glaring of which was the claim that the researchers could screen for viable embryos. This would mean looking at the expression of all 30,000 or so human genes, which is currently not technically possible in any organism, Jaenisch said.

Jaenisch added that even if such technology existed, using it on an embryo would not help, because many genes are expressed only later in development. After the hearing, he said he was concerned that airing the claims of the two groups could taint mainstream science. "These nuts get much too much publicity," he said.

Larry Goldstein of the University of California at San Diego, vice-chairman of the American Society for Cell Biology public policy committee, says he is concerned that such publicity might lead to hasty legislation that would block potentially valuable areas of research.
Bush appoints venture capitalist as technology adviser

Irwin Goodwin, Washington

President George W. Bush has surprised scientists with the appointment of his first main adviser on science and technology.

Bush last week named Floyd Kvamme as co-chairman of the President's Committee of Advisors on Science and Technology (PCAST).

Kvamme is an electrical engineer with a management track record in several Silicon Valley corporations, including National Semiconductor and Apple, and is a partner in the venture-capital firm of Kleiner Perkins Caufield \& Byers in Menlo Park, California. But he is best known in Washington as chairman of the conservative advocacy group Empower America.

Announcing the appointment of Kvamme, Bush said: "He is an entrepreneur. $\mathrm{He}$ is a risk taker. He understands risk and reward. But, more importantly, he knows the players, the people who can bring good, sound advice to this administration."

Bush's decision to appoint Kvamme before filling the post of president's science adviser — who leads the White House Office of Science and Technology Policy (OSTP) and will be PCAST's other co-chair — is seen as unusual by some. In addition, the White House did not consult scientific or engineering societies, or the national academies, which like to provide lists of suitable candidates.

"It's most unusual to name a co-chair of PCAST without having the key figures of the OSTP on board," says Jack Gibbons, who was science adviser to former president Bill Clinton.

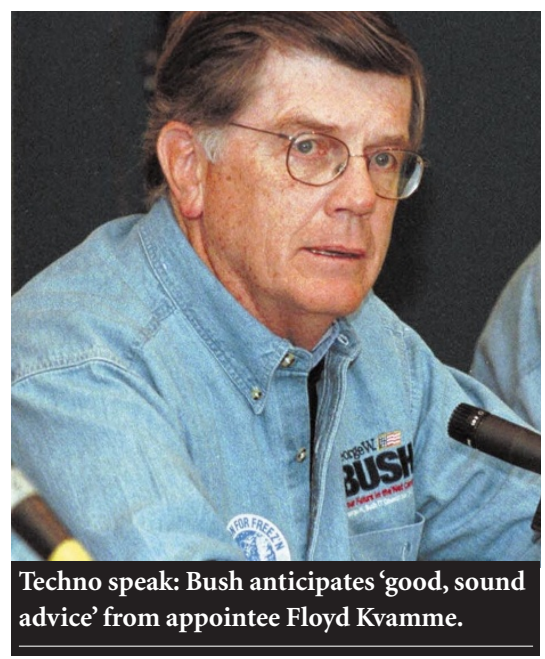

